\title{
Die kerk onderweg na die een en twintigste eeu: \\ 'n Kritiese besinning oor kerkwees in 'n \\ veranderende konteks in Suid-Afrika
}

\section{J S Steenkamp}

Universiteit van Pretoria

Direkteur: Sentrum vir Teologiese Navorsing en Toerusting

\begin{abstract}
The church on its way to the twenty-first century: A critical reflection on being church in a changing context in South Africa

Reflection on the underlying reality of the church in South Africa on its way to the twenty-first century should take into account the dynamic nature of a church. Being a church presupposes the church judging its situation before God. Transition to a new context accentuates the line between the world and the church, since Christianity has finally reached the stage where the world confronts each and every believer as he or she emerges from the doors of his or her church or home. To be a church in this changing context has profound implications for the life and commitment of both the church and the individual believer.
\end{abstract}

\section{INLEIDING}

Die politieke, ekonomiese en sosiale konteks waarin kerk en teologie hulle onderweg na die een en twintigste eeu bevind, is een van ongekende verandering en groot onsekerheid. Hierdie veranderinge raak die totale spektrum van die leefwêreld van lidmate, dit raak die staatkundige, ekonomiese en sosiale strukture waarbinne die kerk en die lidmate van die kerk hulleself vir baie jare in Suid-Afrika gevestig het en waarbinne hulle bepaalde sekerhede beleef het wat deur wetgewing gereël en instand gehou is. Die kerk sal in die nadenke oor die kerk self, oor die kerk se roeping en optrede binne ' $n$ totaal nuwe konteks, opnuut moet worstel oor hoe die beste uitdrukking kan gegee kan word aan die opdrag om kerk van Christus te wees in die tyd en omstandighede wat in die toekoms lê (Moltmann 1975:15). Die saak word verder bemoeilik as gevolg van die feit dat daar in die wetenskap in die algemeen en die teologie in die besonder, self geweldige verskuiwings plaasvind met gepaardgaande onsekerhede en heroriëntering (Oberholzer 1990:870-885). Alhoewel hierdie nadenke oorspronklike en skeppende 
teologiese denke vereis, kan daar nie net voor en oor begin word nie. Daar sal deeglik geluister moet word na dit wat die kerk in verskillende tye en omstandighede oor kerkwees en die opdrag van die kerk gesê het.

Die belydenis credo ecclesiam klink week na week en inderdaad reeds vir eeue in kerke oor die wêreld, maar dit impliseer nie sonder meer dat daar orals en altyd presies dieselfde oor die kerk gedink is of gedink word nie. Elke tydvak vorm 'n eie begrip van die kerk wat medebepaal word deur die situasie en omstandighede waarin die kerk poog om uitdrukking te gee aan die roeping om kerk te wees in en ter wille van die wêreld. Die kerk mag per slot van sake nooit kerk wees ter wille van die kerk self nie, maar is en word weer en weer kerk vir die wêreld. Die kerk is geroep om getuie van die evangelie van Jesus Christus te wees, en dit moet steeds die kerk se diepste begeerte wees om dankend en lofprysend voor haar Heer te leef (kyk Aarflot 1988:7-10).

Die besinning oor die kerkbegrip op die vooraand van die een en twintigste eeu is nie ' $n$ blote teologiese oefening nie, dit is bedoel as indringende dialoog oor kerkwees in 'n nuwe konteks. Hierdie dialoog is noodsaaklik vir die kerk in Suid-Afrika en in die besonder vir die Nederduitsch Hervormde Kerk van Afrika met die oog op die kerk se roeping in 'n snel veranderende wêreld.

$\mathrm{Na}$ die Eerste Wêreldoorlog is daar entoesiasties gepraat van die eeu van die kerk, maar soos die eeu gevorder het, het dit die kerk hoe langer hoe minder geluk om die roeping en taak wat die kerk het, aan die mense van ons tyd bekend te maak (Ulrich 1970:9). Inderdaad is daar talle tekens dat die kerk oral in die wêreld vinnig besig is om as onbeduidende randverskynsel uit die gemeenskap uitgeskuif te word (Van der Ven 1985:9).

Enige besinning oor die kerk moet in sigself 'n appèl uitoefen op die kerk, sodat die lidmate geroep word om saam na te dink oor hulle roeping om kerk in 'n gesekulariseerde wêreld te wees en om tot lof van God te lewe as geloofsgemeenskap (Schillebeeckx 1989a:249-251). Besinning oor die kerkbegrip is daarom deel van die vernuwende aktiwiteit van 'n dinamiese, steeds hervormende kerk binne 'n gegewe konteks waarin God die kerk instuur om die blye evangelie te verkondig en te leef.

\section{WAT IS DIE KERK?}

\subsection{Kerk in die lig van die Skrif}

Ons kan slegs vasstel wat die kerk is as ons weet wat die kerk oorspronklik was. Die probleem is egter dat daar tot nog toe nie daarin geslaag is om 'n enkelvoudige vir almal in alle omstandighede, bevredigende kerkbegrip te formuleer nie (Pelser 1988:15; Van Eck 1991:656-661). Dit is veelseggend dat die Bybel, en in besonder die Nuwe Testament, nie 'n afgeronde omskrywing van die kerk gee nie. Die saak waarom dit 
gaan, word telkens met verskillende terme en beelde uitgedruk. Minear (1960:24) vind meer as tagtig beelde vir die kerk in die Nuwe Testament. So word daar byvoorbeeld na die kerk verwys as uitverkorenes (Rom 1:16; 1 Kor 1:2,9), as volk (2 Kor 6:16; 1 Petr 2:9, 10), as liggaam van Christus (Rom 12:4; 1 Kor 12:13; Ef 1:23), of as getuie (Hand 1:8; Matt 10:5, 16). Volgens Minear (1960:24) is elkeen van hierdie beelde 'n denkvorm, ontwerp om iets te probeer sê van die verhouding tussen die Heer en die kerk, die verhouding waaruit en waarin die kerk bestaan. Mens kan dus nie vanuit die Nuwe Testament sonder meer ' $n$ tegniese leerstuk van die kerk aflei nie. Schnackenburg (1982:15-42) is van mening dat feitlik elke Nuwe-Testamentiese skrywer 'n eie kerkbegrip handhaaf.

\subsection{Enkele momente uit die teologiese nadenke oor die kerk}

Aangesien elke kerk en gevolglik elke teoloog deel is van 'n bepaalde teologiese tradisie en so op die skouers van baie ander staan, is dit gevolglik net nie moontlik om verby hulle, direk na die Skrif terug te gryp nie. Eers nadat elke teoloog die pad van die teologiese tradisie weer oorgeloop het, en weer deur hulle bril van voorgangers teruggekyk het na die gestalte van die kerk soos dit in die ryk gallery van beelde in die Skrif vorm aangeneem het, kan daar besluit word in welke mate daar in die ou bane beweeg moet word en of daar dalk nuwe bane gebreek moet word.

Verskillende sienings uit verskillende teologiese tradisies oor sake soos die verbond, Skrifgesag, heiligmaking, die eskatologie en selfs die denke oor God, vind neerslag in ' $n$ bepaalde kerkbegrip. Die kerkbegrip staan dus nooit los van teologiese besinning nie, maar vloei daaruit voort. Die hele saak kan natuurlik ook andersom plaasvind, naamlik dat die kerkbegrip weer bepalend kan inwerk op die verskillende loci van die geloofsleer. In die tweede eeu met die opkoms van dwaallere, soos die Gnostiek en die Montanisme, was die kerk genoodsaak om sekere kenmerke aan te toon waaraan die ware kerk herken kon word. Die gevolg was dat daar begin is om aan die kerk te dink as ' $n$ instituut, wat deur die biskop as direkte opvolger van die apostels, gelei is. 'n Opeenstapeling van voorbeelde is seker nie nodig nie, daarvoor is die wedersydse beïnvloeding tussen kerkbegrip en teologiese denke te ineengevleg.

Die kerk word dus beperk deur eie insig: enersyds omdat die Skrif nie 'n enkelvoudige en duidelike kerkbegrip voorsien nie, andersyds omdat wisselende historiese situasies verskillende fasette van kerkwees na vore roep. Elke geslag en situasie vra opnuut, vanuit hulle besondere konteks, vrae aan die Skrif in verband met kerkwees, en sodoende word uitsprake in verband met die kerk telkens nuut geformuleer (Schillebeeckx 1989b:53-54). 
Dit is verstaanbaar dat die eenheid van die kerk in die vroeë kerk sterk beklemtoon is, aangesien die kerk in daardie tyd nog maar 'n baie gefragmenteerde beeld vertoon het (Kelly 1968:189-190). Die kerk is éen kragtens die lidmate se geloof in Jesus Christus, die Heer en hoof van die kerk. Die Gees bind die gelowiges saam in die liggaam, die kerk, as geestelike eenheid met Christus die hoof. Die feit dat daar van die Gees as grond van die eenheid van die kerk uitgegaan word, het die gevolg dat daar oor die kerk as 'n pneumatiese gemeenskap gedink is.

Die vraag oor die sigbare en onsigbare kerk was in die vroeë geskiedenis van die kerk nie 'n probleem nie, aangesien daar konkreet oor die kerk as 'n empiriese sigbare gemeenskap gedink is. Dit het egter nie so gebly nie. Reeds Klemens dra Platoniserende idees in die ekklesiologie binne, wanneer hy 'n verskil tussen die sigbare, onvolmaakte kerk, en die volmaakte geestelike kerk maak (Kelly 1968:202-204). So ontstaan die wesenlike gevaar om oor die kerk te dink in terme van 'n Platoniese ideëleer waar die kerkbegrip opgaan in 'n suiwer idee-kerkbegrip. Augustinus maak in sy opvatting oor die kerk 'n onderskeiding tussen die wesenlike kerk, bestaande uit die wat werklik aan Christus behoort, en die empiriese kerk. Hy sien dus die kerk as 'n historiese werklikheid bestaande uit sondaars en regverdiges. Die kerk kan gevolglik nooit anders voorgestel word as 'n corpus permixtum nie (Pont 1987:37; Van Aarde 1987:333).

Beide Rome en die Reformasie sluit by Augustinus aan. Die Roomse ekklesiologie stel deurgaans dat die kerk se wese in die historiese instituut te vinde is, terwyl die Reformasie die wesenlike nie in die historiese vorm sien nie, maar daarin dat dit Christus se kerk is; dat dit aan Hom behoort en dat alle eer en heerlikheid aan Hom toekom en nie aan die kerk of aan die ampte nie. Die Protestantisme leer nêrens 'n wesensgelykheid tussen Christus en die kerk nie, maar lê steeds klem op die onbreekbare eenheid tussen Christus en die kerk. Vraag en antwoord 54 van die Heidelbergse Kategismus bely só oor die kerk:

Dat die Seun van God (a) uit die hele menslike geslag (b) vir Hom 'n gemeente wat tot die ewige lewe uitverkies is (c), deur sy Gees en Woord (d) in die eenheid van die ware geloof (e) van die begin van die wêreld af tot die einde toe (f) vergader, beskerm en onderhou (g), en dat ek daarvan 'n lewende lid is (h) en ewig sal bly (i).

(Diensboek NHKA 1989:181)

Alhoewel die Reformasie die geestelike aard van die kerk beklemtoon, sien hulle die kerk ook daar waar die geestelike oorgaan in die praktyk, waar Woord en die Sakramente sigbaar bedien word aan die adres van 'n gemeente. Die Nederlandse Geloofsbelydenis stel in artikels 27-29 die volgende oor die kerk: 
Ons glo 'n enige, katolieke of algemene kerk, 'n heilige vergadering van almal wat in Christus glo, wat almal hulle volle saligheid in Jesus Christus verwag ... (Artikel 27). Ons glo - aangesien hierdie heilige vergadering ' $n$ versameling is van hulle wat verlos is, en daarbuite geen saligheid is nie ... (Artikel 28). Die kenmerke waaraan ons die ware kerk kan uitken, is die volgende: Wanneer die kerk die evangelie suiwer preek, die sakramente suiwer bedien soos Christus dit ingestel het, en die kerklike tug gebruik om die sondes te straf ....

(Diensboek NHKA 1989:152-153)

Die formulering van die kerkbegrip in die belydenisskrifte bring 'n aantal notae of kenmerke van die kerk ter sprake. Hierdie notae wil nie 'n ideekerk beskryf waarna die kerk moet strewe nie, maar wil eerder 'n gelowige belydenis wees oor die wese van die kerk wat ten diepste eienskappe is van die handelinge van Christus (Moltmann 1975: 363-368).

Die verborge en onsigbare fasette van die kerk moet bedink word, maar nie as 'n absolute beginsel teenoor die konkrete kerkwees van die geloofsgemeenskap rondom Woord en sakramente nie. Die geloof in Christus; die Here van die kerk wat bely word saam met die kerk van alle tye, het dus ook die implikasie dat dit sigbaar word in die heiliging van die lewe van die kerk as geloofsgemeenskap en ook in die eie lewe van elke gelowige.

Die selfverstaan van die Reformatoriese kerk is dat die kerk in die eerste plek kerk van Jesus Christus is. Die Bybel word gesien as die eerste en laaste woord oor die kerk wat beteken dat alles aan die Skrif toetsbaar moet wees as laaste kriterium in die vraag oor wat die kerk wesenlik is. Die kerk gee belydend te kenne dat die kerk enkel uit die geloof lewe en dat die geloof nie gesien word as 'n abstrakte intellektuele aanvaarding van heilsfeite nie, maar as 'n lewende gemeenskap met Jesus Christus. Hierin is iets van ' $n$ eksistensiële beslissing ter sprake wat binne 'n bepaalde verstaanshorison in die geskiedenis geplaas moet word. Die leer oor die kerk het dus primêr te make met dit wat die kerk glo en nie met dit wat mense van die kerk verwag of met dit waarmee mense die kerk wil transformeer nie.

Die gereformeerde ortodoksie het die geloof egter nie gesien as 'n lewende verhouding tussen die geloofsgemeenskap en die Heer van die kerk nie, maar as die meedeel van teologiese doctrina, geformuleer in terme van die Aristoteliese skolastiese wetenskapsideaal. Die kerk sal voordurend daarteen moet waak dat die geloof nie in so 'n abstrakte intellektuele kennisname van heilsfeite verval nie. Waar die verkondiging as eksistensiële gebeure ingeruil word vir die konstatering van 'n stel synswaarhede word die kenniselement van die geloof losgemaak van die konkrete heilsituasie coram Deo waarin dit tot stand gekom het (Koekemoer 1990:710). 
Binne die geledere van die sogenaamde liberale teologie van die negentiende eeu word die kerk gesien as die produk van die vrywillige saamkoms van 'n aantal individuele Christene wat die kerk dan by implikasie sien as van suiwer menslike oorsprong. Individualisering ten koste van sosialisering neem so toe. Persoonlike vryheid word uitgebrei om die aanvaarding van goddelike en kerklike gesag afhanklik te maak van persoonlike keuse en smaak. Die mens word so al meer opgeneem in 'n funksionele samelewingsetiek.

Die teologiese nadenke oor die kerk na die Eerste Wêreldoorlog gee blyke van 'n ontnugtering oor die optimistiese denke oor die mens. Met klem word die Woord in die sentrum gestel en word die Christologie gesien as norm vir die ekklesiologie. Die vraag waarmee gestoei word, is presies waarin hierdie eenheid tussen Christus en die kerk verstaan moet word.

Heinrich Ott (1981:424-428) is van oortuiging dat die wese van die kerk daarin lê dat dit deel het aan die sending van Jesus. Karl Barth (1953:737-740) lê klem daarop dat die kerk aan Jesus Christus behoort; $\mathrm{Hy}$ is die eienaar en die kerk is dit wat uitsluitlik aan Hom behoort. Alhoewel hy Christus en die kerk streng uit mekaar hou, verbind hy Christus en die kerk ook ten nouste. In hierdie lig sien hy dan ook die verband tussen die kerk as liggaam van Christus en die Heer as hoof van die kerk. Soos die kerk by Hom hoort, so hoort Hy by die kerk. Jesus is dus in die midde van die kerk teenwoordig. Die gemeenskap van die gelowiges word bepaal deur die gesamentlike gemeenskap met Christus. Bonhoeffer (1972:38-43) sê dat Christus Heer van die gemeente is, maar ook broeder in die gemeente. Die kerk is vir hom die teenwoordigheid van Christus op aarde. Om dus in die kerk te wees is om 'in Christus' te wees, om deel te wees van die lewende liggaam van Christus.

Die kerk bestaan dus in die eerste plek ter wille van Hom deur Wie dit tot stand gekom het (Getz 1984:48-50). Die kerk is geen terloopse werklikheid nie, maar vind die grond waaruit dit bestaan, in die wil van die Heer wat langs die weg van Jesus uitdrukking wil gee van sy liefde en genade vir die wêreld. Die kerk se selfverstaan kan dus nooit anders wees as dat dit kerk van Jesus Christus is nie. Waar die kerk dus so as 'n gebeure gesien word waar Christus en die kerk in 'n innige verhouding tot mekaar staan, het dit vir die kerk 'n drie-dimensionele betekenis, naamlik 'n gerigtheid na bo, 'n gerigtheid na buite en 'n gerigtheid na binne.

Dit is derhalwe duidelik dat daar nie staties oor die kerk gedink kan word nie. Verskillende beskrywings oor die kerk ontstaan nie omdat die kerk telkens verander nie, maar omdat mense in verskillende situasies sekere aspekte van die veelfassettige, dinamiese kerk raaksien en beklemtoon. 


\section{DIE KERK LEEF UIT DIE HOOR VAN DIE WOORD}

Die Woord wat verkondig word, is niks anders as Jesus Christus wat geopenbaar word nie. Onder hierdie Woordgebeure word die kerk telkens as 'n dinamiese geloofsgemeenskap hervorm en met die evangelie die wêreld ingestuur. Pelser (1994:314) wys daarop dat die verkondiging van die Paasgebeure die stukrag was vir die ontstaan van die kerk. Die heilsgebeure moet egter telkens weer opnuut gehoor word en roep so die hoorder telkens by die hoor daarvan op tot 'n nuwe geloofsbeslising. Die hoorgebeure lei so tot 'n nuwe gelowige selfverstaan. Pelser (1994:315) waarsku tereg dat, as die verkondiging nie elke keer opnuut in elke situasie gestalte aanneem nie, dan verstrak dit tot 'n dooie leer.

Die kerk tree derhalwe dan ook op haar sigbaarste na vore in die erediens waar die evangelie telkens verkondig word. Die kerk is inderdaad soos dit in die erediens voor God kom, en daar word dit by elke verkondiging opnuut weer kerk. Alles wat rondom die erediens gebeur, staan in direkte verband met wat in die erediens gebeur of nie gebeur nie. Die Woordgebeure is 'n ontmoetingsgebeure wat lei tot 'n eksistensiële beslissing by die hoorders. Hierdie geloofsbeslissing word begelei deur die Gees wat die gelowige se lewe vul en beheers.

Die mens wat die Woord elke Sondag in die erediens hoor en dit dan by wyse van spreke in die kerkgebou toesluit tot die volgende Sondag, het nie deel geword van die Woordgebeure nie. Die erediensgebeure word deur so ' $n$ mens as leeg en betekenisloos ervaar.

\section{DIE KERK IS SOOS DIT VOOR GOD IS}

Die wese van die kerk kan alleen bedink word vanuit die werklikheid waar die kerk voor God te staan kom. So kan die kerk sigself sien soos God dit sien. Die kerk kan op geen ander manier voor God te staan kom en standhou as in Jesus Christus nie. Daar kan dus van die kant van die kerk nooit sprake wees van enige eie verdienstelikheid nie, maar alleen van die genade van God. Christus is dus daar vóór die kerk daar was (Berkhof 1973:362; Pelser 1994:314). Die kerk kan daarom nooit anders verstaan word as 'n gemeenskap wat aan die Here behoort nie.

Die gevaar bestaan natuurlik altyd dat mense die kerk vir hulle kan toeëien as hulle kerk. Dit kom dan daarop neer dat mense die kerk as simbool van God se teenwoordigheid in hulle mag probeer kry om só oor God te kan beskik, net soos die Jode die tempel in Jesus se tyd as simbool van God se teenwoordigheid gesien het. Dan gebeur met die kerk wat met die kruis as simbool in die Rooms-Katolieke Kerk gebeur het. Die kerk word dan 'n grootheid op sigself waarin mens met hulle behoeftes gedien word. Ons glo daarom nie in die kerk as iets teenoor ons nie, want ons wat voor God leef, is die kerk wat uit die verhouding met God telkens weer kerk word. 
Die feit dat die kerk alleen kan wees soos dit voor God in Jesus Christus is, beteken nie dat die kerkbegrip in ' $n$ abstrakte vae idee vervloei nie. Dit laat juis die kerk in 'n konkrete situasie leef. Christus in die kerk is nie 'n bowetydelike abstraksie nie, maar 'n lewende Persoon wat deur die Gees in 'n lewende relasie met die lewende gemeenskap van gelowiges staan. Hiermee staan ons meteens voor die wonder van die menswording van die Seun van God. Hierin is ook die eg-menslike van die kerk geleë. 'Die mens Jesus wat uit God is, is die absolute aanvang van die geskiedenis van die kerk' (Van Aarde 1987:333).

Die mense wat hulle heil van Jesus verwag, word Jesus se volgelinge en sy getuies in die wêreld. Hierdie volgelinge is geen super-Christene nie. Die kerk, soos ook elke gelowige, dra soos Jakob, na sy worsteling met God by Jabbok, die tekens van die worsteling. Om kerk voor God te wees kan ook gevaarlik wees vir die kerk as God self ons nie teen onsself beskerm nie. Alleen in Christus kan ons, soos ons is, voor God kom en uit die genade en liefde van God leef. Al wat uiteindelik die onderskeid gemaak het tussen Petrus en Judas was dat die een naby Jesus gebly het waar hy sy skuld in trane bely en vergiffenis ontvang het, terwyl die ander van Jesus verwyder geraak en verlore gegaan het.

\section{KERK AS LIGGAAM VAN CHRISTUS}

Die beeld van die kerk as liggaam van Christus is seker die prominentste van al die Nuwe-Testamentiese aanduidings wat betrekking het op die dinamiese gebeure van kerkwees. Met hierdie beeld wys Paulus op die unieke verhouding wat daar tussen Christus en die kerk en tussen gelowiges onderling bestaan. Die liggaam kan nie sonder die hoof van die liggaam wees nie, maar die hoof wil ook nie sonder die liggaam wees nie. Alhoewel die formule 'in Christus' aanduiding is van die geloofsgemeenskap se behorenheid tot Christus, is dit nog geen identiteitsuitspraak nie. Eenheid is nog nie identiteit nie. By Roomse eksegete loop die beskouing daarop uit dat die kerk, deur identifikasie met die verheerlikte liggaam van Christus, die volheid van die goddelike lewe ontvang (Pelser 1974:155).

Die uitdrukking 'liggaam van Christus' verwys volgens Schweizer (1968:110) na die sfeer waarin Christus se heerskappy uitgeoefen word en waarin gelowiges uit die krag van die Heer leef. Die geloofsgemeenskap is die ruimte waarin gelowiges deur God geroep word om uit Christus se heilsdade te leef en waaruit gelowiges dienswerk aan mekaar verrig. Lewe in die liggaam van Christus is daarom identies aan lewe 'in Christus'. Soos God in Christus uitgereik het na die wêreld, so reik Hy nou na die wêreld uit deur die liggaam van Christus, die gemeenskap wat alleen kan bestaan in verbondenheid met Christus. Die dienswerk wat deur die liggaam van Christus verrig 
word, geskied altyd in gemeenskap. Individuele gelowiges is so op mekaar aangewese (Malina 1986:152-153). Geeneen is in hierdie gemeenskap belangriker as die ander nie (Pannenberg 1993:493-501).

Liefde vorm die konstituerende van die Christelike lewe en plaas die optrede van gelowiges in die ruimte van hierdie geloofsgemeenskap in 'n radikaal nuwe lig (Borg 1994:136). Liefde maak etiese eise in die geloofsgemeenskap oorbodig, want vir hulle by wie daar opregte liefde teenwoordig is, geld die gebod nie meer nie. Gelowiges is met hulle diensbereidheid die gebod eintlik vooruit (Pelser 1995:133). Die lewe van die gelowiges is so gesien die vanselfsprekende van dit waaruit dit voortkom, naamlik die liefde van Jesus. Pelser wys daarop dat die Christelike deugde in Romcine 12:9-21 betrekking het op die onderlinge verhoudinge in die gemeente in die eerste plek, maar daarna ook die verhoudinge met mense buite die gemeente insluit. Dit gaan dus om liefde wat ruimte maak vir dié wat binne is en deure oopmaak vir dié wat buite is (Pelser 1995:133).

Die lewe van die geloofsgemeenskap as liggaam van Christus is dus gemeenskapsonderhoudend sowel as gemeenskapstigtend. Die feit dat die geloofsgemeenskap so as liefdesgemeenskap in diensbereidheid teenoor mekaar en teenoor die wêreld ' $n$ alternatiewe lewensmoontlikheid bied, onderstreep die kragtige getuienis wat van so 'n gemeenskap uitgaan.

Die Gees is die eenheidsband wat die gelowiges in die liggaam van Christus saambind. Die geloofsgemeenskap is daarom 'n pneumatiese gemeenskap en funksioneer as sodanig as die grond van die Nuwe-Testamentiese ekklesiologie (kyk Bultmann 1968: 312; Kourie 1987:41; Van Aarde 1989:468). Uitgaande van die kruisgebeure en opstanding van Christus en saamgebind deur die Gees, is die gelowiges in 'n unieke familieverband verenig waar die liefde vir God en die naaste die lewensbeginsel word en waar gelowiges mekaar eintlik vooruit is in onderlinge sorg vir mekaar (Van Eck 1991:678). Die geloofsgemeenskap as 'n alternatiewe gemeenskap breek so deur alle gangbare en gevestigde sosiale, politieke en kulturele patrone en trek duidelike grense tussen wêreld en kerk (Borg 1994:136). Die getuieniskrag van die geloofsgemeenskap word deur die opregte liefde en onderlinge dienswerk van die lede van die geloofsgemeenskap ondersteun (Van Aarde 1989:473).

Die kerk moet nie as produk van haar dienswerk gesien word nie, want dan loop die geloofsgemeenskap gevaar om in 'n sekere sin van haar dienswerk verwyderd te raak. In die Middeleeue het so'n siening daartoe gelei slegs die ampte, die clerus, bevoeg geag is om die bedieninge van die kerk te onderneem, terwyl die sogenaamde leke, die onkundiges, passief geword het. Dit lei gevolglik tot die dominering van die kerkvolk deur die ampte (Pelser 1994:318-319). 
Die krag van die optiek verbonde aan die onderlinge geloofsgemeenskap moet nooit onderskat word nie. In en deur die beoefening van die gemeenskap van gelowiges ervaar die deelnemers dat die kragte wat saambind, baie sterker is as dié wat skei (Van Niftrik 1961:274-275).

\section{DIE MISSIONÊRE OPDRAG IS WESENLIK TOT KERKWEES}

Die apostolisiteit van die kerk is meer as 'n eienskap van die kerk, dit is voorwaarde vir kerkwees. Die kerk moet verander van een wat stuur na die een wat gestuur is. Bosch stel die missionêre opdrag van die kerk so:

... mission is not primarily an activity of the church, but an attribute of God. God is a missionary God. It is not the church that has a mission of salvation to fulfil in the world; it is the mission of the Son and the Spirit through the Father that includes the world; the church is viewed as an instrument for that mission.

(Bosch 1991:390)

Die kerk is nooit met haar eie missie besig nie. Die kerk is deur die Heer uit die wêreld geroep om in die wêreld ingestuur te word en so deel te neem aan die sending van God. Alle bedieningswyses van die kerk sal dus in die grond van die saak in die apostolêre bewussyn van die kerk geanker moet wees (Van der Merwe 1990:688).

Die spanningsvolle verhouding tussen kerk en wêreld maak dat die kerk nie te ver nie, maar ook nie te naby aan die wêreld moet staan nie. Die kerk moet dis skerp grense tussen die wêreld en die kerk self trek, maar dan ook tegelyk oop en uitgaande na die wêreld wees. Pelser wys op ' $n$ ander paradoks in die kerk se teenwoordigheid te midde van die wêreld, naamlik die van 'n indikatief-imperatief paradoks, waar gelowiges enersyds van hulle verlede en die wêreld geskei is, en andersyds steeds onder die imperatief staan om hierdie skeiding opnuut te bevestig (Pelser 1994:322; vgl ook Bultmann 1968:101-102). Hierdie skerp onderskeiding tussen kerk en wêreld verhoed dat die wêreld die gebied van die kerk betree of dat die kerk verlei word om soos die wêreld te word.

Die missionêre opdrag van die kerk sou dus kragteloos gemaak word indien dit eenvoudig opgaan in 'n bepaalde kultuurvorm. Die implikasie hiervan is van groot belang vir die Nederduitsch Hervormde Kerk van Afrika wat die gedagte van 'n volkskerk in die verlede gunstig beskou het. Die kerk moet in die uitvoering van die verkondigingstaak vry wees teenoor diegene wat met die evangelie gekonfronteer word. Indien die kerk dienstig aan die volk word, dan het die kerk inderdaad niks meer vir die volk te sê nie. Die kerk sal dus die lewe van die volk kerstenend moet binnedring met 'n kritiese ingesteldheid op die lewe van die volk, terwyl dit in gedagte gehou word dat die kerk se heil nie van die volk kom nie, maar van Jesus Christus (Van der 
Westhuizen 1986; Koekemoer 1990:712). In Kerk en wêreld 2000 waarsku die kerk ook tereg daarteen dat afsonderlikheid 'nie verhef word tot die status van evangelie nie — al sou die volk dit hoe sterk van hom verwag' (NHKA 1985:66; kyk ook Van der Merwe 1990:681).

\section{DIE KERK OPWEG NA DIE EEN EN TWINTIGSTE EEU}

Die kerk het in die verlede die nadenke oor die kerk telkens in elke nuwe historiese konteks opnuut in die lig van die Woord voor God gestel. Waar die kerk nou met die oorgang na die een en twintigste eeu oor die wese en roeping van die kerk besin met die oog daarop om kerk te wees in 'n nuwe konteks, moet die kerk ook kennis neem van die aard van die werklikheid wat betree word. Dit kan die kerk baat om kennis te neem van die enkele groot paradigmatiese veranderings wat aangetoon kan word in die geskiedenis van die kerk met die wêreld.

\subsection{Die apostolêre paradigma van die eerste drie eeue na Christus}

Die kerk se selfverstaan is telkens opnuut gevorm vanuit 'n spesifieke teologiese tradisie. In dialoog met die teologiese tradisie en met die Woord word die kerk bewus van die staanplek wat die kerk in 'n gegewe konteks inneem. Ook die vroeë kerk was diep bewus van die krag van 'n geloofsgemeenskap omring, deur 'n vyandige wêreld aan wie hulle die opdrag gehad het om die evangelie van Jesus Christus te verkondig. Hierdie kragtige apostolêre bewustheid en drang het elke gelowige persoonlik aangespreek. So het elke gelowige se voordeur inderdaad 'n poort na en front met die vyandiggesinde wêreld verteenwoordig. Die wêreld wat die kerk ontmoet het, was nie neutraal nie; dit het in alle opsigte teenoor die geloofsgemeenskap te staan gekom. Die sendingopdrag was nie iets wat net sekere gelowiges daar ver moes gaan verrig het nie. Elke gelowige was getuie van die liefde van Jesus die Here vir alle mense. Hulle was elkeen 'n draer van die goeie nuus - die goeie nuus van die verlossing en nuwe lewe in Christus. Hierdie gemeenskap van gelowiges het hulle geroepe gevoel om uit te reik na die wêreld. Daar was duidelike skeidslyne tussen die 'binnekant' en 'buitekant' van die kerk (Barth 1969:20). So groot was die onderskeid tussen kerk en wêreld dat dit 'n dramatiese en kragtige ervaring en gebeurtenis was wanneer iemand by die geloofsgemeenskap aangesluit het.

... by the early second century many Christians judged their religious identity by membership in a local church ... one can trace this sense of identity to an earlier point in time ... and this sense was natured within the social context of their congregations or churches.

(Finney 1994:105) 
Die sentrale fokuspunt van die kerk was die plaaslike gemeenskap van gelowiges, 'n gemeenskap wat geleef het uit die krag van die Gees en die voorbeeld van Jesus. Hierdie gemeenskap van gelowiges was intens by mekaar betrokke. Die betekenis van onderlinge gemeenskap was ook om mekaar op te bou met die oog op hulle roeping. Hierdie eerste drie eeue van die kerk se bestaan kan die apostolêre paradigma genoem word, omdat die geloofsgemeenskap hulleself so totaal op hulle getuienistaak toegespits het. Finney wys daarop dat die vroeë kerk eintlik weinig nagelaat het in terme van kulturele en fisiese dinge.

Hence, in archeological record (as in real life), Christians remain invisible. We cannot see them. We know they are there, but since they have no material distinction, they might as well not be ... Christians had their religious beliefs, they had one another, and not much else ... The only distinction that Christians possessed was their belief system, but this left no marks in the material realm.

(Finney 1994:131)

Tiperend van die apostolêre paradigma is die feit dat die grense tussen kerk en wêreld nie op mekaar gepas het nie en dat die geloofsgemeenskap as alternatiewe gemeenskap bestaan het deur die band van die geloof as enigste maatstaf en binding. Finney stel dit so:

Christians lacked the independent cultural foundations that gave other religions their identity ... Christians had the words of Jesus, the memory of his life and death, and they had one another ... (a) fact whose importance should not be underestimated: ekklesiai were elecmosynary communities of mutual care and concern, and in assesing the growth of Christianity, this fact counts for a great deal.

(Finney 1994:139)

Alhoewel die geloofsgemeenskap 'n brose gemeenskap in die oë van die wêreld was, in die sin dat hulle nie die beskerming en sekuriteit geniet het van 'n sterk etniese of politieke grootheid of 'n eie grondbebied nie, het elke gelowige tog 'n sendingfront volgestaan (Dodds 1965:136-138).

\subsection{Die paradigma van die era van die Christendom}

Die begin van die vierde eeu na Christus verteenwoordig die begin van 'n nuwe paradigma wat die paradigma van die Christendom genoem kan word. Soos in die geval van die apostolêre paradigma het die nuwe paradigma tyd geneem om te vestig. Dit begin met die bekering van keiser Konstantyn tot die Christelike geloof in $313 \mathrm{n} \mathrm{C}$, 
waarvandaan dit progressief momentum gekry het soos die Christendom in naam en by wyse van amptelike wetgewing die offisiële godsdiens van die Romeinse Ryk geword het (Schillebeeckx 1989b:8).

Die kritieke verskil met die voorafgaande paradigma was daarin geleë dat die kerk nou by wyse van wet identies geword het met die ryk. Die wêreld wat die onmiddellike omgewing van die kerk verteenwoordig het, is so identies met die kerk verklaar. Die grense tussen kerk en wêreld het nou deinserig geword en selfs heeltemal verdwyn. Waar die geloofsgemeenskap vroeër intiem en gelokaliseerd was, is die begrip van hierdie geloofsgemeenskap vergroot, sodat dit inderdaad alles ingesluit het in die ryk.

Die missionere front van die kerk het verskuif van die voorstoep van die gelowige se huis na die grense van die staat, ver buite bereik van die gelowige. Christene en die kerk het nou politieke mag, grondgebied en ekonomiese krag ontvang.

Die implikasies van hierdie paradigmaskuif was verreikend vir die geloofsgemeenskap. Die gelowige was nou nie langer meer intiem en direk betrokke by die missionêre taak van die kerk nie _-- die staat of die keiser het dit in werklikheid nou oorgeneem. Die kerk sou hoogstens iemand spesifiek kon afsonder en stuur na die grense van die staat wat nou die nuwe front met die wêreld geword het. Die primêre opdrag aan die kerk en die gelowige om as gestuurde van die Heer die wêreld tegemoet te tree, het algaande op die agtergrond vervaag. Die wêreld op die voorstoep van die gelowige het nou verander in 'n vriendelike omgewing. Om wêreldlinge te bekeer tot die geloof het dieselfde geword as om volke te oorwin vir die staat. Hierdie nuwe verhouding tussen kerk en staat het inderdaad die missionêre gerigtheid van die gelowige en die kerk grondig beïnvloed. Die plaaslike gemeente het hoogstens 'n ondersteunende sisteem geword vir die missionêre werk van die kerk (staat) daar ver weg, buite die grense van die staat onderneem het. Die feit dat die kerk in die vierde eeu staatskerk geword het, het ook daartoe aanleiding gegee dat die eenheid-in-die-instituut gedagte gevestig het (Van Aarde 1987:339).

Eienaardig genoeg, toe die vennootskap tussen kerk en staat begin verval het, was dit meermale die kerk wat ontsteld gereageer het, gedagtig aan die (valse) sekuriteite wat hom ontneem is. Alhoewel die grense tussen kerk en staat verkrummel het, het die paradigma van die Christendom nie eensklaps verdwyn nie. Trouens hierdie paradigma van die Christendom leef voort by baie lidmate en skep 'n valse gerustheid by kerk en lidmate.

Die paradigma van die Christendom is belangrik, omdat die lidmate vandag daarmee opgegroei het en dit hulle denke oor kerk en wêreld bepaal. Hauerwas \& Willimond beskryf hulle eie ervaring van die paradigma van die Christendom so: 
... Church, home, and state formed a national consortium that worked together to instill 'national values'. People grew up Christian simply by being lucky enough to be born in places like Greenville, South Carolina or Pleasant Grove, Texas.

(Hauerwas \& Willimon 1990:16)

Hauerwas \& Willimond beskryf verder hoe hierdie paradigma vir hulle begin sterf het:

When and how did we change? Although it may sound trivial, one of us is tempted to date the shift sometime on a Sunday evening in $1963 \ldots$ Seven of us - regular attenders of the Methodist Youth Fellowship at Buncombe Street Church - made a pact to enter the front door of the church, be seen, then quietly slip out of the back door and join John Wayne at the Fox ... The Fox Theater went head to head with the church over who would provide the world view for the young. That night in 1963, the Fox Theater won the opening skirmish.

(Hauerwas \& Willimon 1990:15-16)

\subsection{Die vestiging van 'n nuwe paradigma}

Die belang van die paradigma van die Christendom vir die kerk op pad na die een en twintigste eeu lê daarin dat lidmate en ampsdraers van die kerk opgegroei het met die paradigma en hulle denke oor kerkwees daardeur beïnvloed is. Strukture wat die kerk en staat in vennootskap opgebou het, soos die sogenaamde Christelike skole en instellings vir barmhartigheidsdiens, is gebou op die vooronderstellings van die Christelike paradigma. Die relieke van hierdie paradigma omring ons en hou ons in 'n sekere sin gevange deur die gewaande sekuriteit wat ons gemeen het dit ons bied.

Alhoewel die begin van hierdie paradigma teruggevoer kan word na die tyd van die Franse Revolusie, het die werklike effek daarvan Europa en Amerika eers van die begin van die tweede helfte van die twintigste eeu getref, toe die werklikheid posgevat het dat kerk en wêreld vreemd vir mekaar geword het. Hierdie ontwikkeling het die kerk in Suid-Afrika met volle geweld en gepaardgaande ontnugtering getref met die veranderende politieke, ekonomiese en sosiale konteks van die laaste paar jaar. Die verwydering tussen kerk en staat mag in woorde nie so dramaties klink nie, maar die implikasies daarvan is ingrypend.

Eerstens kan die kerk en lidmate eenvoudig nie meer aanvaar dat almal rondom hulle Christene is nie. Die kerk as geloofsgemeenskap sal die feit en uitdaging dat die grootste getal van 'n bepaalde gebied se inwoners nie meer geïntereseerd is in die kerk of die Christelike geloof nie, moet verwerk. Die ontnugterende besef behoort egter plek te maak vir 'n bevrydende ervaring by die kerk en die lidmate, aangesien die grense van die wêreld waarheen die kerk gestuur word, weer duidelik geword het. 
Tweedens sal die kerk moet besef dat die breë kulturele gemeenskap of volk in wie se konteks die verkondiging plaasvind, nie meer 'n gemeenskap is wat sonder meer Christelike waardes uitleef en wil beskerm deur wetgewing nie. Sogenaamde Christelike skole, partye en owerhede is na alle waarskynlikheid iets van die verlede.

Derdens lyk dit onvermydelik dat die kerk gereed gemaak sal moet word om in 'n sekere sin terug te keer na een van die kenmerke van die apostoliese paradigma van die eerste eeue van die kerk se bestaan. Die kerk sal moet besef dat die kerk se voordeur en dié van elke gelowige die ontmoetingspunt met die wêreld, 'n post-Christelike wêreld is. Elke gelowige wat oor die drempel van sy/haar huis tree, stap 'n sendingveld binne. Hierdie feit het implikasies op elke lewensterrein soos die van die apostolaat, die barmhartigheidsdiens, die kategese, die jeugwerk, die onderwys, die pastoraat en die prediking. Gelowiges sal eenvoudig elke lewensgebied moet binnegaan soos suurdeeg en die evangelie daar leef en bely.

Die apostoliese paradigma verskil van die nuwe paradigma in die sin dat eersgenoemde 'n dualistiese siening oor kerk en wêreld gehad het, terwyl laasgenoemde 'n meer refleksiewe siening het wat meer akkommoderend staan teenoor dit wat buite die kerk is. In die apostoliese paradigma het ons gesien dat die kerk in 'n neutrale, vyandige wêreld in hegte gemeenskappe van toegewyde gelowiges gegroepeer het.

Waar die grense van die geloofsgemeenskap in die Christelike paradigma porieus en selfs vaag geword het, waar mense in en uit die geloofsgemeenskap beweeg met weinig verantwoordelikheid ten opsigte van mekaar en vir die wêreld, voel die geloofsgemeenskap in die oorgang na die nuwe paradigma onseker en in minder of meerdere mate onbetrokke. Die geloofsgemeenskap ervaar dikwels dat die sekulêre karakter van die wêreldgemeenskap in die hart van die gemeente wortel geskied het. Die verandering van 'n paradigma is per definisie sake wat verband hou met bepaalde persepsies, gevoelens, bewussyn en wêreldopvatting. Daarom is een van die moeilikste probleme waarmee die kerk in so 'n oorgang van een paradigma na 'n ander te kampe kry, die verskynsel dat mense wat in een gemeenskap saamleef, radikaal kan verskil ten opsigte van hulle visie op dinge.

In kort is dit duidelik dat die nood aan 'n sterk stabiele geloofsgemeenskap juis op die tydstip na vore kom wanneer die gemeenskapslewe broos en onseker geword het. In so 'n klimaat antwoord 'n mens gewoonlik deur harder te poog om die ou resep beter te laat werk. Aangesien die kerk nog nie die presiese vorm van die nuwe paradigma kan onderskei nie, is dit belangrik dat daar aan die grondbeginsels van kerkwees vasgehou moet word. As 'n mens nie die land kan sien nie, is dit noodsaaklik om die kaart en kompas te gebruik en kennis te neem van die seestrome en hoe die wind waai.

Die kerk behoort oor die toekoms alleen vanuit die wese van die kerk te praat. Ons kan in geen geleerde en verhewe taal die sorg en liefde in die verhouding tussen Heer en volgelinge en tussen gelowiges onderling beter uitdruk as wat die Woord dit 
beskryf nie. Die gerigtheid op God, op mekaar en op die wêreld word deur verskillende beelde, elk op ' $n$ besondere wyse beskryf.

Julle is ... nie bywoners nie, maar medeburgers van die gelowiges, en lede van die huisgesin van God. Julle is 'n gebou wat opgerig is op die fondament van die apostels en die profete, 'n gebou waarvan Christus Jesus self die hoeksteen is. In Hom sluit die hele gebou saam en verrys dit tot ' $n$ heilige tempel vir die Here, in wie julle ook saam opgebou word as 'n geestelike huis waarin God woon

(Ef 2:19-22)

Julle darenteen, is 'n uitverkore volk, 'n koninklike priesterdom, 'n nasie wat vir God afgesonder is, die eiendomsvolk van God, die volk wat die verlossingsdade moet verkondig van Hom wat julle uit die duisternis geroep het tot die wonderbare lig.

(1 Pet 2:9)

Net soos die liggaam ' $n$ eenheid is ... so is dit ook met die liggaam van Christus .... Julle is die liggaam van Christus en afsonderlik is elkeen 'n lid daarvan ....

(1 Kor 12:12-31)

... om die gelowiges toe te rus vir hulle diens en vir die opbou van die liggaam van Christus.

(Ef 4:12)

Hy is die hoof van die liggaam, die kerk.

Ek is die Goeie Herder. Die goeie herder lê sy lèwe af vir die skape ... hulle sal een kudde wees met een herder ....

(Joh 10:1-16)

Besinning oor die kerk op weg na die een en twintigste eeu kan nie verby die werklikhede en verwagte werklikhede van die hede en die toekoms kyk nie, maar sien dit vanuit die perspektief van die wese van die kerk. Die kern van die saak is hoe die kerk te midde van 'n ingrypend veranderende wêreld kan vashou aan die geloof in die opgestane Heer van die kerk en tersefdertyd die geloof in Christus die Heer verkondig aan die wêreld wat op die kerk se voorstoep te vind is. Daarvoor is daar in 'n sekere sin bekering by die kerk nodig. Die kerk en elke gelowige sal hulle moet losmaak van alle gewaande sekuriteite wat ons almal gemeen het ons in die wêreldse gevind het. Alleen daar waar die kerk as geloofsgemeenskap self voor God gestel word, kan so 'n 
bekering werklikheid word (Oberholzer 1990:1-2; 1993:877-885). Daar begin die kerk leef as lewende liggaam van Christus wat met 'n apostolêre gerigtheid uitgaan na die wêreld en met liefde en toewyding na mekaar omsien.

Die voordeel van so 'n nuwe paradigma is dat die kerk en wêreld nie meer as verlengstukke van mekaar funksioneer nie. Wanneer die kerk in hierdie nuwe paradigma voor die owerheid getuig, kan die kerk alleen staatmaak op die krag van die evangelie wat die kerk verkondig.

Alhoewel die begeerte by baie leef om van hierdie nuwe werklikheid af weg te vlug en hulle terug te trek in die veiligheid van ' $n$ introverte nabinne-gerigtheid, sal ons juis so'n begeerte moet onderdruk (Van Zyl 1963:4). So'n siening kom neer op 'n apokaliptiese verstaan van die toekoms wat die kerk daartoe verlei om in 'n kloosterlewe te onttrek. Die einde van ' $n$ era is nie die einde van God se bemoeienis met die wêreld nie. Dit kan eerder ' $n$ nuwe begin wees. Dit beteken nog genadetyd wat aan ons gegun word.

\section{GEVOLGTREKKING}

In die besinning oor die kerk se wese en roeping in die wêreld het dit duidelik geword dat die kerk telkens sal moet oordeel hoe die kerk voor God moet verskyn. Die kerk kan dit op geen ander manier doen as onder die Woord-gebeure nie. Daar leef die gelowiges as alternatiewe gemeenskap in diensbetoning en met die liefde wat tegelyk gemeenskaponderhoudend en gemeenskapstigtend is. Dit beteken dat die predikate of eienskappe wat tradisioneel aan die kerk geheg word, nie as statiese synskategorieë verstaan en op die kerk toegepas moet word nie, maar in dinamiese sin verstaan moet word binne elke nuwe konteks. So is die kerk van die kruis en opstanding af op pad na die toekoms, 'n toekoms waar die kerk opnuut kerk moet word vir 'n post-Christelike wêreld, tot eer van die God deur Wie se genade dit bestaan.

Die kerk sal dus steeds op pad moet wees, bedag op verstarring, selfvoldaanheid en gearriveerdheid. Hierdie op weg wees is dus nie net 'n op weg wees deur die wêreld nie, maar ook en veral 'n op weg wees na 'n eie identiteit, 'n identiteit wat die kerk reeds in Christus het, maar wat telkens opnuut moet realiseer.

In lyn met ons teologiese tradisie moet ons daarop bedag wees om nie net na binne gerig te lewe nie, maar om baie meer aandag te gee aan die apostolêre gerigtheid van die kerk in 'n nuwe konteks. Wat nou miskien vir ons na 'n verleentheid mag lyk, is na alle waarskynlikheid eerder 'n geleentheid om die evangelie aan die wêreld te bring. Een ding wat ongetwyfeld baie duidelik is, is dat God die kerk in diens neem vir sy wêreldgerigte sending. Ons moet ons nie terugtrek in ons huise en kerke nie, maar die lig vir die wêreld wees, waar ons eredienste, ons gemeentelewe en ons teenwoordigheid midde in die wêreld, soos 'n lamp op 'n berg skyn. 
Die kerk van die Reformasie is 'n kerk wat die onrus ken. Die Reformatore het opnuut besef dat die waarheid van waaruit die kerk leef, nie die besit van die kerk is waaroor eiemagtig beskik word nie, maar 'n waarheid wat oor die kerk self beskik. In die lig van hierdie waarheid sal ons ons gedagtes oor die kerk, ook ons gewoontes en gebruike, telkens weer moet oorweeg, aangesien ons in die loop van die tyd so gewoond daaraan kon geraak het, dat ons dalk nie meer opmerk dat dit nie te rym is met die wese van die kerk nie.

Ons hoop is nie op iets nie, maar op Iemand gerig. Ons sal daarom in die geloof moet vashou aan die wete dat die wêreld steeds God se wêreld is en bly. Juis daarom is daar vir die gelowige ' $n$ toekomsverwagting, want die toekoms behoort nie aan die heidendom of ' $n$ neutrale staat nie, maar aan God.

Ons sal ook 'n bron van hoop vir mekaar moet wees, deur opnuut te ontdek wat die gemeenskap van gelowiges in opregte liefde vir God en medemens en sorg vir mekaar werklik beteken.

\section{Literatuurverwysings}

Aarflot, A 1988. Let the church be the churh. Minneapolis: Augshurg.

Barth, K 1953. Kirchliche Dogmatik, IV/1. Zürich: EVZ.

Berkhof, H 1973. Christelijke Geloof. Nijkerk: Callenbach.

Bonhoeffer, D 1972. Het wezen van de kerk, saamgestel deur Otto Dudzus. Baarn: Ten Have.

Borg, M 1994. Meeting Jesus again for the first time. San Francisco: Harper.

Bosch, D J 1991. Transforming mission. Mary Knoll: Orbis.

Elliott, J H 1981. Home for the homeless. Philadelphia: Fortress.

Dodds, E R 1965. Pagan and Christian in an age of anxiety. Cambridge: Cambridge University Press.

Finney, P C 1994. The invisible God. New York, Oxford: Oxford University Press.

Getz, G A 1974. Shapening the focus on the church. Chicago: Moody.

Hauerwas, S \& Willimon, H 1990. Resident aliens. Nashville: Abingdon.

Kelly, J N D 1968. Eary Christian doctrines. Londen: Black.

Koekemoer, J H 1990. Die na-binne of introverte gerigtheid van 'Kerk en wêreld 2000'. HTS 46, 708-715.

Kung, H 1978. The church. Londen: Search.

Malina, B J 1986. Interpreting the Bible with anthropology: The case of the poor and the rich. Listening 21, 148-159.

Minear, P S 1960. Images of the church in the New Testament. Philadelphia: Westminister. 
Moltmann, J 1975. Kirche in der Kraft des Geistes. Munchen: Kaiser.

Nederduitsch Hervormde Kerk van Afrika 1987. Diensboek. Pretoria: Kital.

Nel, M 1994. Gemeentebou. Johannesburg: Orion.

Oberholzer, J P 1990. Daar is bekering nodig. Die Hervormer, Februarie 1990, bl 12.

- 1993. Die teologiese eie-aardigheid van die Nederduitsch Hervormde Kerk: Vrae en nuanses. HTS 49, 870-886.

Ott, H 1981. Die Antword des Glaubens. Stuttgart: Callenbach.

Pannenberg, W 1993. Systematische Theologie. Göttingen: Vandenhoek.

Pelser, G M M 1988. Die bedieninge in die Nuwe Testament: 'n Ondersoek na historiese wording en prinsipiële oorweging. Praktiese Teologie in Suid-Afrika 5/1, 1-18.

- 1994. Wese van die kerk. HTS 50, 311-329.

- 1995. Kerk as gemeenskap van gelowiges. Almanak, 132-134. Pretoria: Tydskrifafdeling van die Nederduitsch Hervormde Kerk van Afrika.

Pont, A D 1987. Die vrye kerk: Enkele opmerkings oor die herkoms en inhoud van die opvatting. HTS 43, 25-46.

Schillebeeckx, E 1989a. Mensen als verhaal van God. Baarn: Nelissen.

- 1989b. Een demokratiese kerk. Baarn: Nelissen.

Schnackenburg, R 1961. Die Kirche im Neuen Testament. Freiburg: Herder.

Schweizer, E 1978. Jesus. London: SCM Press.

Ulrich, H 1970. Umstrittene Frage der Ekklesiologie. Regensburg: Friedrich Pustet.

Van Aarde, A G 1987. Gedagtes oor die begin van die kerk - 'n geskiedenis van versoenende verskeidenheid. HTS 43, 325-351.

- 1989. 'n Nuwe-Testamentiese begronding van die eenheid van die kerk en die eis om kerkeenheid vandag. HTS 45, 461-475.

Van Eck, E 1992. 'n Sosiaal-wetenskaplike ondersoek na die 'amp' van die ouderling in die Nuwe Testament. HTS 47, 656-684.

Van der Merwe, P J 1990. Die Nederduitsch Hervormde Kerk en sy bediening in 'n toekomstige Suid-Afrika: Die visie van 'Kerk en wêreld 2000'. HTS 46, 672-689.

Van der Ven, J A 1985. Toekomst voor de kerk? Studies voor Frans Haarsma. Kampen: Kok.

Van Niftrik, G C 1961. Kleine Dogmatiek. Nijkerk: Callenbach.

Van Zyl, F J 1962. Kerk en wêreld. Die Hervormer, Februarie 1963, bl 4. 